[Denpun Kagaku, Vol.40, No.3, p. 305 310 (1993)]

\title{
A Novel Method of Fermentative Production of Calcium Lactate Directly from Noncooked White Rice Bran
}

\author{
Mark M. Shamtsian,* Tsutomu OKubo,** Masakazu Murai,** \\ Djong-Chi CHU,** Varuzhan H. AbEliAn,* Kyohei MizoKAMI*** \\ and Takehiko YAMAMOTO*** \\ * Microbiology Institute of Armenian Academy of Science \\ (Abovian, Armenia) \\ ** Central Research Laboratories, Taiyo Kagaku Co., Ltd. \\ (1-3, Takara-cho Yokkaichi 510, Japan) \\ *** Department of Biotechnology, Fukuyama University \\ (Sanzo, 1, Gakuen-cho, Fukuyama 729-02, Japan)
}

\begin{abstract}
Calcium lactate was found to be produced directly from noncooked white rice bran by using Streptococcus bovis, which is a rumen bacterium and known to be capable of digesting raw starch. The starch was suspended in a dilute solution of sulfuric acid ( $\mathrm{pH}$ about 2) and after allowing the mixture to stand for several hours, calcium carbonate was added to it to make carbon dioxide evolve, followed by inoculation of the bacterium. The amount of starch converted to lactate per unit time was increased with the starch concentration to some extent. Of interest was the fact that the addition of small amount of glucoamylase to the fermentation mixture resulted in a significant acceleration of the fermentation.
\end{abstract}

The lactic acid fermentation is one of the most important microbial industries and a great number of papers have so far been published. It is known that the acid produced and accumulated during the lactic acid fermentation retards the growth of bacterial cells by killing them, thereby the extent of lactic acid production is limited. ${ }^{1-3)}$ It has also been known that the lactic acid of the undissociated form is the primary agent to retard the bacterial growth. ${ }^{4,5)}$ To overcome this problem, calcium carbonate has been used to obtain calcium lactate as the end-product in the fermentation.

The saccharification of raw starch has also been an economic factor to limit the fermentative production of lactate..$^{6,7)}$ To solve this problem, saccharification of raw starch by application of glucoamylase, which is capable of hydrolysis of noncooked starch, may be worthy as an investigation subject. ${ }^{8-11)}$ Recently, Hoshino and his coworkers reported a paper on continuous lactic acid production from raw starch, a reversibly soluble and autoprecipitating amylase and immobilized cells of Lactobacillus casei. ${ }^{12)}$

In the present paper, the fermentative production of calcium lactate from white rice bran, a kind of raw rice starch, by using Streptococcus bovis is described in regard to the conditions, especially to the method of sterilization of raw starch and the effect of addition of glucoamylase to accelerate the starch saccharification. The results including the fermentation yield and isolation method of calcium lactate produced are also discussed.

\section{MATERIALS AND METHOD}

Materials. For calcium-lactate production, white rice bran* produced as a by-product in

* In rice grain refining process, especially in obtaining polished rice for sake making, surface of rice grain is scraped stepwise. The waste bran produced at first is called as "Akanuka" (brown bran)which consists of the most portion of aleurone layer. The next bran obtained in the later step of rice polishing is called "Shironuka" (white rice bran) and consists of relatively inner part of starch layer of rice grain. 
rice refining process for sake making was exclusively used.

The starch content of the white rice bran was estimated to be $70 \%$ by the phenol sulfuric acid method. For sterilization, the rice bran was suspended in several weights of $0.02 \sim$ $0.04 \mathrm{~N}$ sulfuric acid at room temperature for $5 \mathrm{hr}$ and then, calcium carbonate was added to the starch suspension to neutralize the acid and to have carbon dioxide saturated. In the experiments the rice starch treated with the acid and neutralized with calcium carbonate was used as "rice starch medium." The amount of calcium carbonate added to the medium was $45 \mathrm{~g}$ per $100 \mathrm{~g}$ white rice bran.

Microorganism and culture medium. The microorganism used for lactic acid fermentation was Streptococcus bovis No. 148 isolated from calf rumen as a homo-fermentative $\mathrm{L}-(+)$-lactic acid producer. The bacterium has also been characterized to be capable of digesting raw cereal starch into glucose and maltose by Kitahara and Mizokami. ${ }^{13)}$

The inoculum was prepared by culture of the bacterium in a test-tube containing $10 \mathrm{ml}$ medium consisted of $2 \%$ glucose, $0.5 \%$ yeast extract (DIFCO, USA) and $0.5 \%$ Bacto Peptone (DIFCO, USA) (glucose medium $\mathrm{pH}$ 6.0). After one-day incubation at $37^{\circ} \mathrm{C}$, the culture was used as inoculum.

The microorganisms were also cultivated in $500 \mathrm{ml}$ Erlenmeyer flasks containing $400 \mathrm{ml}$ of $8 \%$ or $12 \%$ white rice bran under constant temperatures. This medium was inoculated with two test-tube culture described above by which the amount of microorganisms reached $10^{7}$ cells per $\mathrm{ml}$. When a $10 l$ jar fermentor with $8.5 l$ medium was used, the rice starch medium (8.5l) was agitated for a few $\min (60$ $\mathrm{rpm})$ at every $6 \mathrm{hr}$ with adjusting the $\mathrm{pH}$ at 6. 0 , with manually feeding $6 \mathrm{~N}$ sodium hydroxide. The temperature $\left(40^{\circ} \mathrm{C}\right)$ was regulated by circulation of temperature-controlled water.

For determination of the optimum $\mathrm{pH}$ and temperature of the cell growth and lactic acid production, the batch culture method was employed with using $2 \%$ "glucose medium."

Glucoamylase used was of Rhizopus delemar prepared by Shin Nihon Chem. Ind. Co., Ltd., as "Sumizyme 2000." The addition of this enzyme was usually in a rate of $0.035 \%$ towards white rice bran in the medium.

Fermentations were also examined with or without adding to the medium $2 \%$ of a baker's yeast decoction $\left(20 \mathrm{~g}\right.$ in $1.0 \mathrm{l}, 100^{\circ} \mathrm{C}, 1 \mathrm{hr}$, filtrate) or $2.5 \%$ of a white potato decoction $(25 \mathrm{~g}$ in 1. $0 \mathrm{l}, 100^{\circ} \mathrm{C}, 1 \mathrm{hr}$, filtrate) or both of them. The effect of the addition of milk whey $(\mathrm{pH} 4.7$, supernatant) was also examined by adding in a ratio of $10 \%$ to the medium.

Analytical methods. The cell density of inoculum and its growth were measured by optical absorbance at $562 \mathrm{~nm}$. Also, the cell growth during the fermentation using white rice bran was determined by aseptically sampling an aliquot of the culture, diluting and plating it on an agar medium for counting colonies to appear in a carbon dioxide incubator.

The total sugar content in the media was determined by the phenol-sulfuric acid method and expressed as glucose equivalent. Existence of starch in the culture was qualitatively estimated by iodine color reaction.

The identification of calcium lactate was done by TLC using butanol-acetic acid-water (4: $0.5: 1)$ as solvent and detected with $0.5 \%$ bromophenol blue in $0.2 \%$ aqueous citric acid. The content of lactic acid was determined by using the lactic acid determination kits (Boehringer Mannheim, Germany) and with high performance liquid chromatography using "Eyela" liquid chromatograph PLC 5D equipped with "Biorad" column for organic acid analysis "Aminex" ion exclusion HPX-87H.

Calculation of fermentation efficiency. The rates of starch consumption and lactic acid production were expressed using the following formula:

$$
\begin{aligned}
& \mu_{\mathrm{S}}=d S / X d T \\
& \mu_{\mathrm{L}}=d L / X d T
\end{aligned}
$$

where $\mu_{\mathrm{S}}$ and $\mu_{\mathrm{L}}$ are specific rate of starch consumption and specific rate of lactate production. $T$ is time $(\mathrm{hr}), X$, cell concentration and $S$ and $L$ are glucose concentration (total sugar content) and lactic acid concentration, respectively.

\section{RESULTS}

Effects of temperature and $p H$ on cell growth and lactic acid production. In the 


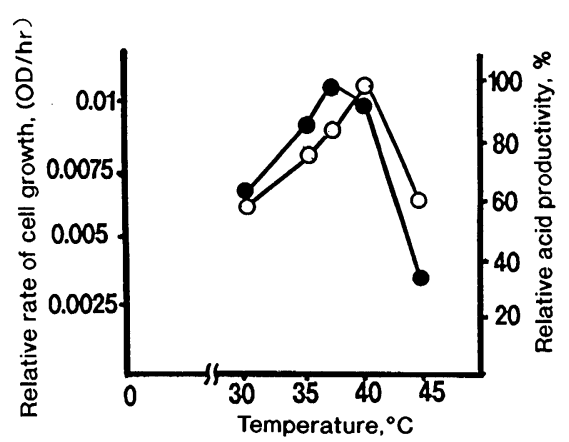

Fig. 1. Lactic acid production and cell growth at different temperatures.

Lactic acid production and cell growth were investigated at $\mathrm{pH} 7.0$ but at different temperatures for $24 \mathrm{hr}$ incubation. $\bigcirc$, Lactic acid; $\bullet$, cell growth.

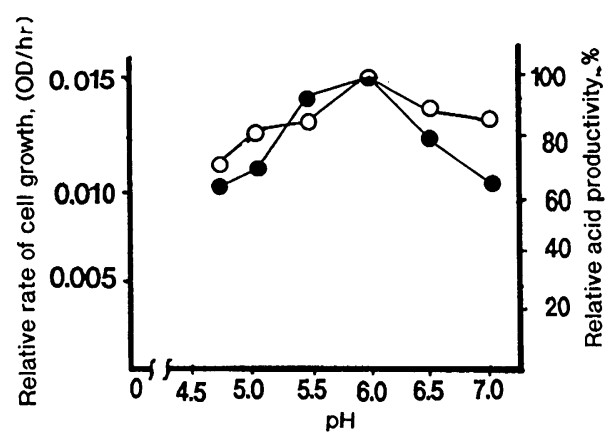

Fig. 2. Lactic acid production and cell growth at different $\mathrm{pH}$.

Lactic acid production and cell growth were examined as a function of $\mathrm{pH}$ on $24 \mathrm{hr}$ incubation at $40^{\circ} \mathrm{C}$. O, Lactic acid; $\bullet$, cell growth.

experiment performed by controlling culture at $\mathrm{pH} 7.0$, the optimal temperature for cell growth was $37^{\circ} \mathrm{C}$, although the maximum rate of lactate production was obtained at $40^{\circ} \mathrm{C}$ (Fig. 1). On the other hand, when cultured at 40 ${ }^{\circ} \mathrm{C}$, the optimal $\mathrm{pH}$ for cell growth and lactic acid production was at 6.0 (Fig. 2).

Fermentation profile of white rice bran of several concentrations. In Fig. 3 is shown the starch digestion rate by Streptococcus bovis to produce lactic acid on 25, 50, and $100 \mathrm{~g}$ white rice bran per 1 medium. The result indicates that the culture with $2.5 \%$ rice starch produced lactic acid in amount equivalent to almost $70 \%$

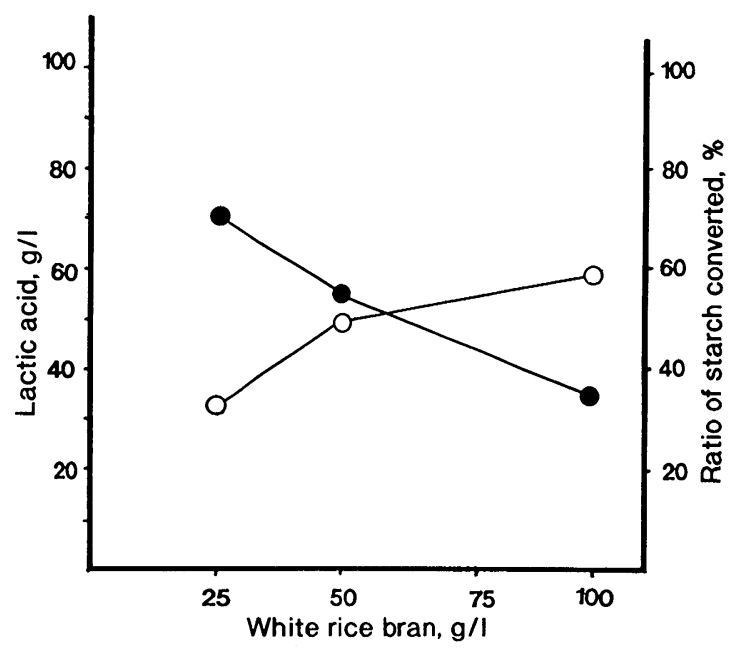

Fig. 3. Consumption of starch and lactic acid production efficiency on different concentrations of white rice bran.

Analysis was carried out after $66 \mathrm{hr}$ incubation at $\mathrm{pH} 6.0$ and $40^{\circ} \mathrm{C}$. O, Lactic acid produced, $\mathrm{g} / l$; -, ratio of starch converted to lactic acid, $\%$.

of white rice bran in $66 \mathrm{hr}$, while the culture with $10 \%$ rice starch produced the acid only $34 \%$ against rice bran in the same incubation time.

Effect of the addition of glucoamylase, decoctions of baker's yeast or potato and milk whey on fermentation. Table 1 shows the relationship between the fermentation periods to attain the maximum of lactic acid production and the initial concentrations of white rice bran with or without addition of glucoamylase, yeast decoction, potato decoction, or milk whey. By the addition of glucoamylase $(0.035 \%$ against white rice bran), the fermentation period to reach the maximum of lactic acid production was greatly shortened and the sufficent periods were $42 \mathrm{hr}$ and $85 \mathrm{hr}$ for $8.0 \%$ and $12 \%$ white rice bran, respectivly. Effects of addition of milk whey, yeast and potato decoctions were observed to be positive, but not so significant as glucoamylase to shorten the fermentation period.

Time course of lactic acid production. The time course of lactic acid production at initial $\mathrm{pH} 6.4$ and at $40^{\circ} \mathrm{C}$ was investigated using 400 $\mathrm{ml}$ of $8.0 \%$ white rice bran in $500 \mathrm{ml}$ Erlenmeyer flask which was initially acidified and 
Table 1. Comparison of incubation periods (hr) to attain the maximum lactic acid production with or without additions.

\begin{tabular}{cccccc}
\hline & \multicolumn{3}{c}{ Additions } \\
\hline $\begin{array}{c}\text { white rice bran } \\
\text { added }(\%)\end{array}$ & None & Glucoamylase* & $\begin{array}{c}\text { Glucoamylase*+ } \\
\text { milk whey** }\end{array}$ & $\begin{array}{c}\text { Yeast*** and } \\
\text { potato*** } \\
\text { decoctions }\end{array}$ & $\begin{array}{c}\text { Glucoamylase*+ } \\
\text { yeast and potato } \\
\text { decoctions*** }\end{array}$ \\
\hline 12 & 140 & 85 & 74 & 118 & 80 \\
8 & 70 & 42 & 42 & &
\end{tabular}

* The amount of glucoamylase was $0.035 \mathrm{~g}$ per $100 \mathrm{~g}$ white rice bran. ** Milk whey was added in a rate of $10 \mathrm{ml}$ per $100 \mathrm{ml}$ medium. *** Decoctions were added in a rate of $10 \mathrm{ml}$ per $100 \mathrm{ml}$ medium.

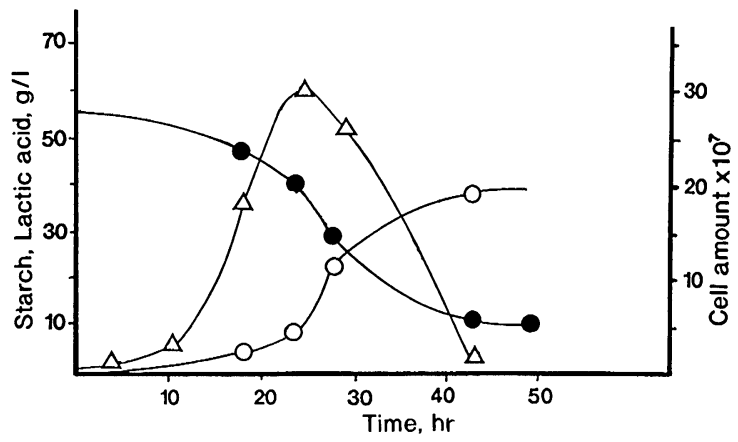

Fig. 4. Time course of lactate fermentation on $8 \%$ white rice bran.

The time course was investigated incubating the fermentation mash at $40^{\circ} \mathrm{C}$ and at $\mathrm{pH} 6.4$ (initial) with the addition of glucoamylase in a ratio of $0.035 \%$ towards white rice bran. O, Lactic acid; , remaining starch; $\triangle$, cell growth.

then, neutralized by adding $14 \mathrm{~g}$ of calcium carbonate. The result shown in Fig. 4 indicates that lactic acid production began and proceeded in parallel with the cell growth. However, before the starch was almost consumed, the cell amount abruptly decreased and lactic acid production downed slow.

Fermentation kinetics. Figure 5 shows the maximum of specific glucose consumption rate and specific lactate production rate calculated from the data of Fig. 4. As the fermentation proceeded, the specific lactic acid production rate approached the specific glucose consumption rate. This fact indicates that the conversion rate from starch (glucose) to lactic acid becomes theoretical as the fermentation proceeds to a certain fermentation stage.

Isolation of calcium lactate. The lactic acid produced by fermentation at $40^{\circ} \mathrm{C}$ for $42 \mathrm{hr}$ in

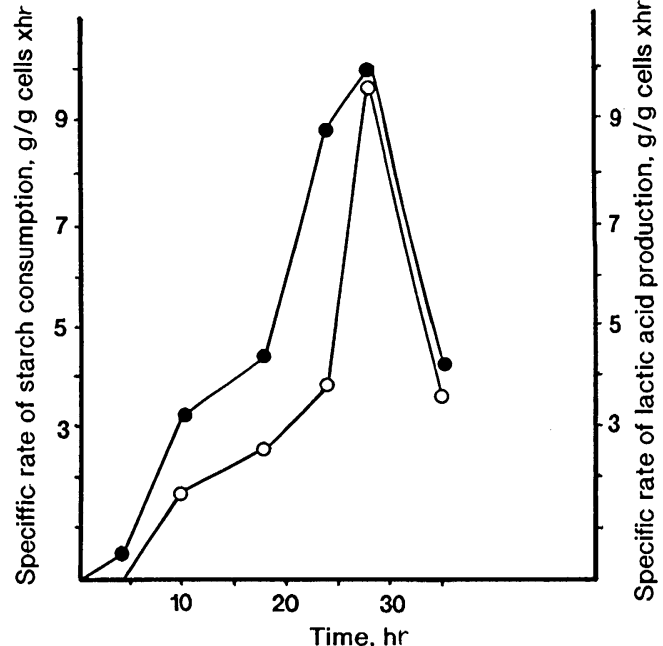

Fig. 5. Fermentation kinetics of $8 \%$ white rice bran.

Specific glucose consumption and lactate production rates on $8 \%$ white rice bran were calculated from the data of Fig. 4. O, Specific rate of lactic acid production; 0 , specific rate of starch consumption.

$10 l$ jar fermentor $(680 \mathrm{~g}$ white rice bran in $8.5 l$ with $0.035 \%$ glucoamylase) was purified. The culture medium was filtered through a cloth filter, the filtrate was alkalized with calcium hydroxide to $\mathrm{pH}$ about 9.4 and heated at $80^{\circ} \mathrm{C}$ for $30 \mathrm{~min}$. After filtration, the filtrate was neutralized with lactic acid to $\mathrm{pH} 6.5$ and subjected to decoloration with active charcoal $(0.2 \%)$. The decolored filtrate was concentrated to about $20 \%$ calcium lactate and allowed to stand in the cold overnight. The resulting crystal mass was washed with cold water and recrystallized by the same way as above. The recrystallized calcium lactate was dried in current air of $45^{\circ} \mathrm{C}$ to a constant weight. 
The analysis with HPLC for the purified calcium lactate showed the same elution patern as the authentic specimen and the purity of the purified preparation was more than $98 \%$.

\section{DISCUSSION}

The fermentative lactate production was examined. Streptococcus bovis, a rumen bacterium having activity to hydrolyze noncooked starch was used as acid producer. White rice bran, a waste product at rice polishing to make Japanese sake, was used as the raw material. For fermentation the rice bran was used and its sterilization was done by steeping it into a dilute sulfuric acid $(0.02-0.04 \mathrm{~N})$ for several hours at room temperature (about $23^{\circ} \mathrm{C}$ ). It was found that steeping the rice bran into dilute sulfuric acid was effective not only for sterilization of the substrate, but also for causing evolution of carbon dioxide upon addition of calcium carbonate. The amount of calcium carbonate to be added was settled to be slightly more than the equivalent for neutralization of lactic acid produced and causing evolution of carbon dioxide. Among these factors, concentration of substrate seemed to be the most important for lactic acid production under the conditions.

The absolute quantity of lactic acid to be produced from the substrate in a unit of time was found to increase with increase in substrate concentration. However, the efficiency rate (the rate of lactic acid production against the substrate in a unit of time) rather decreased with increase of substrate. In the present study, a mixture of $8 \%$ of white rice bran $(5.6 \%$ as starch) and calcium carbonate in amount of $45 \mathrm{~g}$ per $100 \mathrm{~g}$ white rice bran was found to be completely fermented for $70 \mathrm{hr}$. It was interesting that the addition of Rhizopus glucoamylase $(0.035 \%$ of white rice bran) shortened the fermentation period to $42 \mathrm{hr}$. However, the addition of more amounts of glucoamylase did not result in further acceleration of fermentation. Effects of the addition of yeast- or potato-decoctions on the fermentation were also investigated. However, their additions were not so effective as glucoamylase.

In the fermentation, relatively a long lag phase (about $8 \mathrm{hr}$ ) was observed. This may be improved by increasing the amount of inoculum. On the other hand, maximum values of specific glucose consumption and lactic acid production rates appeared in the exponential growth phase but after this stage of the fermentation, their curves declined rapidly. This phenomenon may be due to not only the decrease of substrate, but also the decrease in $\mathrm{pH}$ by rapid lactic acid production during the exponential growth phase. Thus the concentration of white rice bran as substrate for lactic acid production was considered to be $8 \%$, if the fermentation period was limited within two days.

The present paper presents a novel method of lactic acid production using Streptococcus bovis as the lactic acid producer, Rhizopus glucoamylase as a saccharification helper and white rice bran as the substrate. This paper also suggests an application means of starchy waste.

\section{REFERENCES}

1) M. R. FRIEDMAN and E. L. GADEN : Biotechnol. Bioeng., 12, 961-974 (1970).

2) T. B. Vick ROY, H. W. BlANCH and C. R. WILKE : Biotechnol. Lett., 4., 483-488 (1981).

3) A. IsHizAKI and T. OHTA : J. Ferment. Bioeng., 67, 46-51 (1989).

4) A. A. HARRERO : Trends Biotechnol., 1, 49-53 (1983).

5) R. K. BAJPAI and E. L. IANNOTTI : in Handbook of anaerobic Product inhibition, L. E. ERICKSON and D. Y.-C. FUNG, ed., fermentations : Marcell Dekker, Inc., New York p. 207-241 (1988).

6) M. TANiguchi, K. Hoshino, Y. Netsu and M. FUJII : J. Chem. Eng., 22, 313-318 (1959).

7) K. Hoshino, M. TANiguchi, H. Marumoto and M. FujII : Agric. Biol., Chem., 53, 1961-1966 (1989).

8) S. Takao, H. Sasaki, K. Kurosawa, M. TANidA and Y. Kamagata : Agric. Biol. Chem., 50, 1979-1984 (1987).

9) T. Yамамото, ed. : Handbook of Amylases and related enzymes, Pergamon Press, Oxford, 195-226 (1988).

10) K. Mikuni, M. Monma and K. Kainuma : Biotechnol. Bioeng., 29, 729-733 (1987).

11) F. M. BERGMAN, J. ABE and S. HizUKURI : Appl. Microbiol. Biotechnol., 27, 443-447 (1988). 
12) K. Hoshino, M. TANiguchi, H. Marumoto, K. SHIMIZU and M. FujII : Agric. Biol. Chem., 55, 479-485 (1991).

13) K. Mizokami, M. KozaKi and S. Kitahata : Nippon Nogeikagaku Kaishi, 51, 299-307(1977).

(Received December 14, 1992 ; accepted January 25, 1993)
乳酸カルシウムの無蒸煮白糠からの 直接発醳生産

マーク M. シャムチャン*，大久保 勉**， 村井正和**, 朱 政治**, バルジャン H. アベリアン*,

溝上恭平***, 山本武彦***

*アルメニア国科学アカデミー微生物研究所

(アルメニア国アボビアン市)

** 太陽化学秼総合研究所

（510 四日市市宝町 1-3）

*** 福山大学工学部生物工学科

（729-02 福山市学園町 1 三蔵）

牛のルーメンから分離した生澱粉分解能を有する Streptococcus bovis を使って乳酸カルシウムを無蒸煮 白棣から直接生産できることがわかった，澱粉を希薄な 硫酸溶液中 $(\mathrm{pH}$ 約 2$)$ に数時間浸漬させて減菌し, 次 いで炭酸カルシウムを加えて $\mathrm{CO}_{2}$ ガスを発生, 飽和さ せて菌を接種した. 単位時間当りの澱粉の乳酸転換率は, ある程度まで潵粉濃度に比例した. 少量のグルコアミ ラーゼの培地への添加は, 発酵をかなり促進した. 